\title{
Pengaruh Tingkat Pendidikan, Pengalaman Kerja, Independensi, dan Gaya Kepemimpinan terhadap Efektivitas SPI BUMD Kota Denpasar
}

\author{
I Gede Yoga Trisna Widya ${ }^{1}$ \\ I Gde Ary Wirajaya ${ }^{2}$
}

${ }^{1,2}$ Fakultas Ekonomi dan Bisnis Universitas Udayana (Unud), Bali, Indonesia e-mail: trisnayoga59@yahoo.co.id

\begin{abstract}
ABSTRAK
Penelitian ini bertujuan untuk memperoleh bukti empiris pengaruh tingkat pendidikan, pengalaman kerja, independensi, dan gaya kepemimpinan terhadap efektivitas Sistem Pengendalian Internal BUMD Kota Denpasar. Metode pengumpulan data dalam penelitian ini adalah metode survei. Jumlah populasi adalah 32 Satuan Pengawas Internal di 3 (tiga) BUMD Kota Denpasar. Metode penentuan sampel menggunakan teknik sampel jenuh, sehingga sampel yang digunakan berjumlah 32 Satuan Pengawas Internal. Teknik analisis data yang digunakan dalam penelitian ini adalah analisis regresi linier berganda. Hasil penelitian ini menunjukkan bahwa tingkat pendidikan, pengalaman kerja, independensi, dan gaya kepemimpinan secara parsial berpengaruh positif terhadap efektivitas Sistem Pengendalian Internal BUMD Kota Denpasar.

Kata Kunci: Tingkat Pendidikan, Pengalaman Kerja, Independensi, Gaya Kepemimpinan, Efektivitas Sistem Pengendalian Internal
\end{abstract}

\begin{abstract}
This study aims to obtain empirical evidence of the influence of the level of education, work experience, independence, and leadership style on the effectiveness of the Denpasar City BUMD Internal Control System. The method of data collection in this study is a survey method. The population is 32 Internal Control Units in 3 (three) BUMD in Denpasar City. The sampling method uses a saturated sample technique, so that the sample used was 32 Internal Control Units. The data analysis technique used in this study is multiple linear regression analysis. The results of this study indicate the level of education, work experience, independence, and leadership style partially have a positive effect on the effectiveness of the Denpasar City BUMD Internal Control System.

Keywords: Level of Education, Work Experience, Independence, Leadership Style, Effectiveness of the Internal Control System
\end{abstract}

\section{PENDAHULUAN}

Sistem Pengendalian Internal sangat penting dalam menunjang perbaikan pengelolaan suatu perusahaan dan merupakan faktor pendukung untuk menciptakan tata kelola yang akuntabel dan transparan sebagai cerminan dari kinerja yang baik. Sistem Pengendalian Internal didefinisikan oleh (Abiola, 2013) sebagai tindakan yang dilakukan pada keuangan dan non-keuangan untuk 
memastikan perlindungan aset, deteksi dan pencegahan penipuan, memenuhi persyaratan dan prosedur kebijakan internal kontrol dan akurasi kelengkapan catatan.

Menurut Peraturan Pemerintah Republik Indonesia Nomor 54 Tahun 2017 tentang Badan Usaha Milik Daerah dijelaskan bahwa BUMD adalah badan usaha yang seluruh atau sebagian besar modalnya dimiliki oleh daerah. BUMD dalam menjalankan usahanya harus berdasarkan tata kelola perusahaan yang baik sebagai cerminan kinerja yang baik. Berkaitan dengan kinerja, kurangnya pengawasan internal di beberapa BUMD di Indonesia masih terasa. Hal ini terlihat dari masih ditemukannya kelemahan Sistem Pengandalian Internal pada BUMD oleh BPK.

Temuan BPK Tahun 2015 atas pemeriksaan terhadap BUMN dan BUMD dalam dua semester menunjukan bahwa permasalahan di bidang Sistem Pengendalian Internal dan tata kelola masih sangat besar. Pada semester satu terdapat 729 permasalahan dan semester dua terdapat 641 permasalahan. Selain itu berdasarkan temuan dalam Ikhtisar Hasil Pemeriksaan Semester (IHPS) II Tahun 2016 terdapat kerugian sebesar Rp 19,48 triliun akibat kelemahan Sistem Pengendalian Internal dan ketidakpatuhan terhadap peraturan perundangundangan. Nilai itu mencakup 5.810 temuan yang memuat 1.393 kelemahan Sistem Pengendalian Internal dan 6.210 masalah ketidakpatuhan terhadap peraturan perundang-undangan. IHPS II Tahun 2016 merupakan ringkasan dari 604 laporan hasil pemeriksaan (LHP) yang diselesaikan BPK. LHP itu meliputi 81 LHP (13\%) pada pemerintah pusat, 489 LHP (81\%) pada pemerintah daerah dan BUMD, serta 34 LHP (6\%) pada BUMN dan badan lain (Bisnis.com, 2017). 
Selain itu di beberapa daerah di Indonesia juga masih ditemui beberapa kasus korupsi dan penyelewengan yang terjadi di BUMD, seperti kasus korupsi di PDAM Kota Makasar yang terindikasi merugikan Negara sebesar Rp 45.844.159.840 (Merdeka.com, 2015). Kasus korupsi lain terjadi di PD Pasar Pakuan Jaya Kota Bogor, dimana terjadi dugaan korupsi investasi dana penyertaan modal pemerintah sebesar Rp 15 miliar (Liputan6.com, 2018) dan PD Pasar Surya Surabaya, dimana terjadi dugaan korupsi dana revitalisasi pasar senilai Rp 14,8 miliar (Kompas.com, 2018).

Berdasarkan temuan-temuan di atas, maka diperlukan peningkatan pengawasan yang dilakukan di masing-masing BUMD di Indonesia. Untuk merealisasikan hal tersebut diperlukan Satuan Pengawas Internal dalam BUMD yang berkompeten. Satuan Pengawas Internal adalah unit kerja yang membantu Pimpinan Instansi dalam mengawasi dan mengevaluasi Sistem Pengendalian Internal sehingga mengarahkan jalan Instansi dalam jalur yang benar. Ada beberapa hal yang perlu diperhatikan untuk meningkatkan efektivitas Sistem Pengendalian Internal di masing-masing BUMD yaitu, dengan meningkatkan kompetensi Satuan pengawas Internal yang ada di BUMD dengan melihat tingkat pendidikan yang dimiliki.

Semakin tinggi tingkat pendidikan pegawai, maka pegawai tersebut akan memiliki pengetahuan yang lebih memadai dan memudahkannya dalam melakukan pengawasan dengan lebih efektif. Kualitas Satuan Pengawas Internal juga dapat dilihat dari pengalaman kerja yang dimiliki. Dengan masa kerja yang lebih lama pegawai akan lebih berpengalaman dan cenderung mengingat lebih 
banyak tugas sehingga pegawai tersebut memiliki kemampuan untuk menyelesaikan tugas yang diberikan dengan lebih baik dan meminimalkan kesalahan dalam melakukan pengawasan internal. Satuan Pengawas Internal dihaharapkan memliki independensi yang tinggi, yaitu dalam melakukan pengawasan mampu besikap objektif dan jujur sehingga ketika melakukan pengawasan tidak memihak dalam menilai prosedur dan kebijakan yang telah ditetapkan. Hal lain yang penting diperhatikan adalah gaya kepemimpinan dari pimpinan BUMD Karena gaya kepemimpinan dari seorang atasan kepada pegawainya akan berdampak terhadap efektivitas pengendalian internal (Wicaksono, 2013). Berdasarkan uraian diatas peneliti tertarik untuk meneliti "Pengaruh Tingkat Pendidikan, Pengalaman Kerja, Independensi dan Gaya Kepemimpinan terhadap Efektivitas Sistem Pengendalian Internal BUMD Kota Denpasar".

Penelitian ini didasarkan atas teori stewardship yang mengaitkan hubungan antara pimpinan BUMD sebagai principal dan Satuan Pengawas Internal sebagai steward dimana dalam penelitian ini fungsi teori stewardship untuk menjaga kepercayaan dari pimpinan BUMD kepada Satuan Pengawas Internal untuk melakukan pengawasan internal sesuai dengan kepercayaan yang diberikan. Pendidikan merupakan proses pembelajaran untuk menghimpun dan meningkatkan pengetahuan. Pendidikan diperoleh melalui pembelajaran secara terstruktur dan dalam waktu yang relatif lama. Pendidikan dalam bidang tertentu (spesialisasi) latar belakang pendidikan akan meningkatkan pengetahuan pada bidang berkenaan. Penelitian (Bhuaneswari \& Damayanthi, 2018), menyatakan 
bahwa tingkat pendidikan berpengaruh positif terhadap efektivitas pengendalian internal LPD di Kota Denpasar, hal ini karena seorang pengawas internal yang memiliki tingkat pendidikan yang sesuai dengan fungsi pengawas internal akan lebih memahami suatu prosedur maupun kebijakan yang menunjang pengendalian internal LPD dimana kebijakan-kebijakan yang ada telah dilaksanakan dengan baik sehingga efektivitas pengendalian internal LPD tersebut meningkat. Penelitian lain yang dilakukan (Mirawati, 2014) menyatakan bahwa tingkat pendidikan pegawai perusahaan tekstil berpengaruh positif terhadap efektivitas Sistem Pengendalian Internal.

Tingkat pendidikan yang memadai merupakan hal yang penting dalam peningkatan kualitas Satuan Pengawas Internal dalam upaya untuk meningkatkan efektivitas Sistem Pengendalian Internal suatu organisasi. Berdasarkan uraian diatas dapat dirumuskan hipotesis sebagi berikut:

$\mathrm{H}_{1}$ : Tingkat pendidikan berpengaruh positif terhadap efektivitas Sistem Pengendalian Internal BUMD Kota Denpasar

Pengalaman kerja sesorang menunjukkan jenis-jenis pekerjaan yang telah dilakukan sesorang dan memberikan peluang besar bagi sesorang untuk melakukan pekerjaan yang lebih baik. Auditor yang berpengalaman cenderung tidak melakukan kesalahan yang besar dibandingkan dengan yang tidak berpengalaman (Apsari \& Gayatri, 2018). Menurut penelitian yang dilakukan (Wijaya, Arifati, \& Suprijanto, 2016) menyatakan pengalaman kerja berpengaruh positif terhadap efektifitas penerapan Sistem Pengendalian Internal pada auditor internal yang bertugas di perusahaan pembiyaan se Kabupaten Kudus. Menurut (Ekayanti, Sujana, \& Wahyuni, 2017) pengalaman kerja berpengaruh positif dan 
signifikan secara statistik terhadap efektivitas Sistem Pengendalian Internal Lembaga Perkreditan Desa se-Kecamatan Payangan. Pengalaman pegawai dalam bekerja akan memberikan kemampuan bagi pegawai tersebut terutama kemampuan dalam menjabarkan tugas pokok dan fungsi serta tanggungjawabnya yang terdapat didalam struktur organisasi dan standar operasional prosedur yang ada. Berdasarkan uraian tersebut dapat dirumuskan hipotesis sebagai berikut:

$\mathrm{H}_{2}$ : Pengalaman kerja berpengaruh positif terhadap efektivitas Sistem Pengendalian Internal BUMD Kota Denpasar

Independensi merupakan sikap yang bebas dari hambatan, memberi opini yang objektif, tidak bias, tidak dibatasi, dan melaporkan masalah yang terjadi sebenarnya, bukan berdasarkan keinginan eksekutif atau lembaga. Penelitian (Wijaya et al., 2016) menyatakan bahwa indpendensi auditor internal berpengaruh positif terhadap efektivitas Sistem Pengendalian Internal Perusahaan Pembiayaan se Kabupaten Kudus. Penelitian ini sejalan dengan penelitian (Putra, Herawati, \& Purnamawati, 2017) yang menyatakan independensi berpengaruh positif dan signifikan terhadap efektivitas Sistem Pengendalian Internal BUMDES.

Independensi Satuan Pengawas Internal diperlukan agar dalam melakukan pengawasan mapu memberi laporan suatu kejadian atau temuan sesuai fakta yang sebenarnya. Berdasarkan uraian tersebut dapat dirumuskan hipotesis sebagai berikut:

$\mathrm{H}_{3}$ : Independensi berpengaruh positif terhadap efektivitas Sistem Pengendalian Internal BUMD Kota Denpasar.

Gaya kepemimpinan merupakan seni ataupun proses untuk mempengaruhi sekelompok orang sehingga mereka mau bekerja dengan sungguh - sungguh 
untuk meraih tujuan kelompok. pada organisasi tersebut.Berkaitan dengan gaya kepemimpinan, penelitian yang dilakukan (Kibtiyah \& Sari, 2017) menemukan bahwa gaya kepemimpinan seorang pemimpin dianggap mempunyai peranan pada kinerja pejabat pengadaan. Gaya kepemimpinan akan memengaruhi kinerja Satuan Pengawas Internal, sebab salah satu hal yang dapat mengaruhi efektivitas pelaksanaan pengendalian internal adalah adanya pemantauan yang cukup oleh pimpiman instansi terkait. Berdasarkan uraian tersebut dapat dirumuskan hipotesis sebagai berikut:

$\mathrm{H}_{4}$ : Gaya kepemimpinan berpengaruh positif terhadap efektivitas Sistem Pengendalian Internal BUMD Kota Denpasar.

\section{METODE PENELITIAN}

Penelitian ini merupakan penelitian kuantitatif yang berbentuk asosiatif. Penelitian ini dilakukan di BUMD yang ada di Kota Denpasar yang berjumlah 3 (tiga) BUMD yang berbentuk Perusahaan Daerah. Waktu penelitian dilakukan pada Tahun 2018 dengan memberikan kuesioner pada instansi yang dijadikan sampel.Objek dari penelitian ini adalah tingkat pendidikan, pengalaman kerja, independensi, dan gaya kepemimpinan yang memengaruhi efektivitas Sistem Pengendalian Internal BUMD Kota Denpasar.

Definisi operasional variabel dalam penelitian ini berupa sejumlah pernyataan dalam kuesioner yang berhubungan dengan variabel yang hendak diukur anatara lain:Tingkat pendidikan adalah jenjang pendidikan pegawai yang diukur dengan tingkat atau strata pendidikan mulai dari SMA sampai dengan pasca sarjana (S3) yang dimiliki oleh pegawai. Adapun variabel tingkat 
pendidikan akan diukur dengan 7 (tujuh) pernyataan yang diadopsi dari kuesioner (Wardani, 2014). Indikator kuesioner dari tingkat pendidikan adalah: latar belakang pendidikan, strata pendidikan, dan pendidikan dilakukan secara periodik.

Pengalaman kerja adalah ukuran tentang lama waktu atau masa kerja yang telah ditempuh seseorang dalam memahami tugas-tugas suatu pekerjaan dan telah melaksanakan dengan baik. Adapun variabel pengalaman kerja akan diukur dengan 10 (sepuluh) pernyataan yang diadopsi dari kuesioner (Wardani, 2014). Indikator kuesioner dari pengalaman kerja adalah: jangka waktu bekerja, bidang pengalaman kerja, dan manfaat pengalaman kerja dibidang pengawasan.

Independensi merupakan sikap yang bebas dari pengaruh, tidak dikendalikan pihak lain, dan tidak bergantung pada pihak lain. Adapun variabel independensi akan diukur dengan 4 (empat) pernyataan yang diadopsi dari kuesioner (Rose, 2015). Indikator dari kuesioner independensi adalah: tanggung jawab, integritas, obyektivitas, dan ketaatan. Gaya kepemimpinan adalah kemampuan seorang pemimpin dalam memengaruhi bawahan atau pegawainya sehingga mereka akan berusaha, rela, dan berkomitmen terhadap tujuan organisasi. Variabel gaya kepemimpinan akan diukur dengan 6 (enam) pernyataan yang diadopsi dari kuesioner (Wicaksono, 2013). Indikator kuesioner gaya kepemimpinan adalah: relasi pimpinan dengan bawahan, struktur tugas, dan posisi kekuatan

Sistem Pengendalian Internal merupakan suatu cara untuk mengarahkan, mengawasi, dan mengukur suatu sumber daya organisasi serta berperan penting dalam pencegahan dan pendeteksian penggelapan. Adapun variabel Efektivitas 
Sistem Pengendalian Internal akan diukur dengan 9 (semblan) pernyataan yang diadopsi dari kuesioner (Soimah, 2014). Indikator kuesioner dari Sistem Pengendalian Internal adalah: lingkungan pengendalian, penilaian resiko, kegiatan pengendalian, informasi dan komunikasi, serta pemantauan.

Data primer dalam penelitian ini adalah skor jawaban kuesioner yang disebarkan kepada responden penelitian di masing-masing BUMD di Kota Denpasar. Data sekunder dalam penelitian ini adalah daftar BUMD di Kota Denpasar. Metode pengumpulan data yang digunakan dalam penelitian ini adalah dengan metode survey dengan menggunakan kuesioner. Populasi yang digunakan dalam penelitian ini adalah pegawai Satuan Pengawas Internal pada BUMD Kota Denpasar. Pada lingkungan Pemerintah Kota Denpasar terdapat 3 (tiga) BUMD, yaitu PD Pasar, PD Parkir, dan PDAM. Sampel dalam penelitian ini adalah seluruh pegawai Satuan Pengawas Internal di 3 (tiga) BUMD di Kota Denpasar, yaitu PD Pasar, PD Parkir, dan PDAM yang dipilih menggunakan teknik sampel jenuh. Metode penentuan sampel yang digunakan di dalam penelitian ini yakni nonprobability sampling dengan teknik sampel jenuh. Sampel jenuh adalah teknik penentuan sampel bila semua anggota populasi dijadikan sampel. Dalam penelitian ini sampel yang akan daiambil adalah seluruh Satuan Pengawas Internal di masing-masing BUMD di Kota Denpasar, yaitu PD Pasar, PD Parkir, dan PDAM sebanyak 32 orang responden.

Hasil pengumpulan data dalam penelitian ini akan diolah dengan bantuan program SPSS untuk menguji hipotesis yang telah ditetapkan apakah diterima aatau ditolak. Analisis dalam penelitian ini menggunakan analisis regresi linear 
berganda untuk mengetahui atau memperoleh gambaran mengenai pengaruh Tingkat Pendidikan $\left(\mathrm{X}_{1}\right)$, Pengalaman Kerja $\left(\mathrm{X}_{2}\right)$, Independensi $\left(\mathrm{X}_{3}\right)$ dan Gaya Kepemimpinan $\left(\mathrm{X}_{4}\right)$, terhadap Efektivitas Sistem Pengendalian Internal (Y).Model regresi linear berganda dalam penelitian ini ditunjukan dengan persamaan berikut.

$\mathrm{Y}=\alpha+\beta_{1} \mathrm{X}_{1}+\beta_{2} \mathrm{X}_{2}+\beta_{3} \mathrm{X}_{3}+\beta_{4} \mathrm{X}_{4} e$

Keterangan:

$\mathrm{Y}=$ efektivitas Sistem Pengendalian Internal

$\alpha=$ konstanta

$\beta_{1}=$ koefisien regresi tingkat pendidikan

$\beta_{2}=$ koefisien regresi pengalaman kerja

$\beta_{3}=$ koefisien regresi independensi

$\beta_{4}=$ koefisien regresi gaya kepemimpinan

$\mathrm{X}_{1}=$ tingkat pendidikan

$\mathrm{X}_{2}=$ pengalaman kerja

$\mathrm{X}_{3}=$ independensi

$\mathrm{X}_{4}=$ gaya kepemimpinan

$e=$ tingkat kesalahan atau tingkat gangguan

Hasil analisis yang dilakukan diatas dapat diamati Goodnes of Fit-nya yaitu: koefisien determinasi $\left(\mathrm{R}^{2}\right.$ ), uji kelayakan model (uji F) serta uji hipotesis (uji t).

\section{HASIL DAN PEMBAHASAN}

Responden yang dipilih dalam penelitian ini adalah 32 orang Satuan Pengawas Internal di masing-masing BUMD yang dijadikan sampel yaitu: PD Pasar, PDAM, dan PD Parkir. Satuan Pengawas Internal merupakan bagian atau unit kerja yang bertugas Membantu direktur utama dalam melaksanakan pemeriksaan operasional dan keuangan, menilai pengendalian, pengelolaan, dan pelaksanaan di Instansi tersebut serta memberikan saran perbaikan. 
Memberikan keterangan tentang hasil pemeriksaan atau hasil pelaksanaan tugas Satuan Pengawas Internal kepada direktur utama. Memonitor tindak lanjut atas hasil pemeriksaan yang dilaporkan.

Tabel 1.

Ringkasan Pengiriman dan Pengembalian Kuesioner

\begin{tabular}{lcc}
\hline \multicolumn{1}{c}{ Kuesioner } & Jumlah & Persentase (\%) \\
\hline Kuesioner yang disebarkan & 32 & $100 \%$ \\
Kuesioner yang kembali & 32 & $100 \%$ \\
Kuesioner yang digunakan & 32 & $100 \%$ \\
\hline Sumber: Data diolah, 2018 & &
\end{tabular}

Berdasarkan Tabel 1 dapat diketahui bahwa jumlah kuesioner yang tersebar ke responden sebanyak 32 kuesioner dan kembali sebanyak 32 kuesioner. Semua kuesioner yang kembali diisi dengan lengkap sehingga secara keseluruhan sebanyak 32 kuesioner yang dapat digunakan.

Uji validitas merupakan pengujian instrumen penelitian sebagai suatu derajat ketepatan alat ukur penelitian tentang inti atau arti sebenarnya yang diukur. Berdasarkan Tabel 2 instrumen-instrumen pada setiap variabel dalam penelitian ini memiliki nilai pearson corelation yang lebih besar dari 0,30 sehingga dapat disimpulkan bahwa, seluruh butir dalam instrumen penelitian ini dikatakan valid atau dapat dinyatakan layak digunakan sebagai alat ukur.

Uji reliabilitas digunakan untuk mengetahui keandalan instrumen penelitian.Teknik yang digunakan adalah dengan mengukur nilai Cronbach' Alpha. Suatu pernyataan dikatan reliabel jika nilai alpha lebih besar dari 0,70 . Adapun hasil dari uij realibilitas dapat ditunjukkan pada Tabel 3. 
Tabel 2.

Hasil Uji Validitas

\begin{tabular}{|c|c|c|c|}
\hline Variabel & Item & $\begin{array}{c}\text { Pearson } \\
\text { Corelation } \\
\end{array}$ & Keterangan \\
\hline \multirow[t]{7}{*}{ Tingkat Pendidikan } & $\mathrm{X} 1.1$ & 0,926 & Valid \\
\hline & $\mathrm{X} 1.2$ & 0,820 & Valid \\
\hline & $\mathrm{X} 1.3$ & 0,842 & Valid \\
\hline & $\mathrm{X} 1.4$ & 0,864 & Valid \\
\hline & $\mathrm{X} 1.5$ & 0,834 & Valid \\
\hline & X1.6 & 0,729 & Valid \\
\hline & $\mathrm{X} 1.7$ & 0,842 & Valid \\
\hline \multirow[t]{10}{*}{ Pengalaman Kerja } & $\mathrm{X} 2.1$ & 0,845 & Valid \\
\hline & $\mathrm{X} 2.2$ & 0,736 & Valid \\
\hline & $\mathrm{X} 2.3$ & 0,705 & Valid \\
\hline & $\mathrm{X} 2.4$ & 0,756 & Valid \\
\hline & $X 2.5$ & 0,756 & Valid \\
\hline & $\mathrm{X} 2.6$ & 0,796 & Valid \\
\hline & $\mathrm{X} 2.7$ & 0,833 & Valid \\
\hline & $\mathrm{X} 2.8$ & 0,832 & Valid \\
\hline & $\mathrm{X} 2.9$ & 0,696 & Valid \\
\hline & $\mathrm{X} 2.10$ & 0,815 & Valid \\
\hline \multirow[t]{4}{*}{ Independensi } & X3.1 & 0,852 & Valid \\
\hline & X3.2 & 0,870 & Valid \\
\hline & X3.3 & 0,814 & Valid \\
\hline & X3.4 & 0,773 & Valid \\
\hline \multirow[t]{6}{*}{ Gaya Kepemimpinan } & $\mathrm{X} 4.1$ & 0,834 & Valid \\
\hline & $\mathrm{X} 4.2$ & 0,779 & Valid \\
\hline & $\mathrm{X} 4.3$ & 0,782 & Valid \\
\hline & $\mathrm{X} 4.4$ & 0,860 & Valid \\
\hline & $\mathrm{X} 4.5$ & 0,805 & Valid \\
\hline & $\mathrm{X} 4.6$ & 0,804 & Valid \\
\hline \multirow[t]{8}{*}{ Efektivitas Sistem Pengendalian Internal } & Y1 & 0,803 & Valid \\
\hline & $\mathrm{Y} 2$ & 0,767 & Valid \\
\hline & Y3 & 0,870 & Valid \\
\hline & Y4 & 0,762 & Valid \\
\hline & Y5 & 0,815 & Valid \\
\hline & Y6 & 0,951 & Valid \\
\hline & Y7 & 0,855 & Valid \\
\hline & Y8 & 0,814 & Valid \\
\hline
\end{tabular}

Sumber: Data diolah, 2018

Berdasarkan Tabel 3 yang meliputi tingkat pendidikan, pengalaman kerja, independensi, gaya kepemimpinan, dan efektivitas Sistem Pengendalian Internal masing-masing memiliki nilai Cronbach'Alpha0,926; 0,925; 0,839; 0,891; dan 
0,938. Semua instrumenn dinyatakan reliabel karena memiliki nilai Cronbach' Alphalebih dari 0,70.

Tabel 3.

Hasil Uji Reliabilitas

\begin{tabular}{rlcr}
\hline No. & Variabel & Cronbach's Alpha & Keterangan \\
\hline 1 & Tingkat Pendidikan & 0,926 & Reliabel \\
2 & Pengalaman kerja & 0,925 & Reliabel \\
3 & Independensi & 0,839 & Reliabel \\
4 & Gaya Kepemimpinan & 0,891 & Reliabel \\
5 & Efektivitas Sistem Pengendalian Internal & 0,938 & Reliabel \\
\hline
\end{tabular}

Sumber: Data diolah, 2018

Uji asumsi klasik terdiri dari uji normalitas, uji multikolinearitas, dan uji heterokedastisitas. Hasil uji asumsi klasik dapat dilihat pada Tabel 4 berikut.

Tabel 4.

Hasil Uji Asumsi Klasik

\begin{tabular}{|c|c|c|c|c|c|}
\hline \multirow{2}{*}{ No } & \multirow{2}{*}{ Keterangan } & \multirow{2}{*}{$\begin{array}{c}\text { Uji } \\
\text { Normalitas }\end{array}$} & \multicolumn{2}{|c|}{ Uji Multikolinearitas } & \multirow{2}{*}{$\begin{array}{c}\text { Uji } \\
\text { Heterokedastisitas } \\
\text { Sig. }\end{array}$} \\
\hline & & & Tolerance & VIF & \\
\hline 1 & Tingkat Pendidikan $\left(\mathrm{X}_{1}\right)$ & & 0,131 & 7,633 & 0,924 \\
\hline 2 & Pengalaman Kerja $\left(\mathrm{X}_{2}\right)$ & & 0,111 & 8,973 & 0,691 \\
\hline 3 & Independensi $\left(\mathrm{X}_{3}\right)$ & & 0,357 & 2,799 & 0,794 \\
\hline 4 & $\begin{array}{r}\text { Gaya Kepemimpinan }\left(\mathrm{X}_{4}\right) \\
\text { Asymp. sig }\end{array}$ & 0,455 & 0,273 & 3,668 & 0,882 \\
\hline
\end{tabular}

Sumber: Data diolah, 2018

Berdasarkan Tabel 4 hasil uji normalitas memiliki nilai Asymp.Sig (2tailed) sebesar 0,455 (lebih besar dari 0,05). Hal ini berarti data telah terdistribusi normal.Berdasarkan Tabel 4 dapat dilihat bahwa model regresi ini tidak terjadi multikolinearitas. Hal ini dapat dilihat dari tidak ada variabel independen yang memiliki nilaitolerance kurang dari 0,10 dan nilai Variance Inflation Factors (VIF) diatas 10 .Tingkat pendidikan mempunyai nilai tolerance 0,131 , pengalaman kerja mempunyai nilai tolerance 0,111 independensi mempunyai nilai tolerance 0,357, gaya kepemimpinan mempunyai nilai tolerance 0,273 . Sedangkan tingkat pendidikan mempunyai nilai VIF 7,633, pengalaman kerja mempunyai nilai VIF 
8.973, independensi mempunyai nilai VIF 2.799, dan gaya kepemimpinan mempunyai nilai VIF 3.668.

Berdasarkan Tabel 4 hasil uji heterokedastisitas, dengan jelas menunjukkan bahwa nilai signifikansi masing-masing variabel di atas $\alpha=0,05$. Dimana nilai signifikansi tingkat pendidikan sebesar 0,924 >0,05, pengalaman kerja sebesar $0,691>0,05$, independensi sebesar 0,794 >0,05, dan gaya kepemimpinan sebesar 0, $882>0,05 . J a d i$, dapat disimpulkan bahwa model regresi tidak mengandung adanya heteroskedastisitas.

\section{Tabel 5.}

Hasil Analisis Regresi Linier Berganda

\begin{tabular}{|c|c|c|c|c|c|}
\hline \multirow[b]{2}{*}{ Variabel } & \multicolumn{3}{|c|}{$\begin{array}{c}\text { Unstandarized } \\
\text { Coefficients }\end{array}$} & \multirow[t]{2}{*}{$\mathbf{t}$} & \multirow[t]{2}{*}{ Sig. } \\
\hline & & $\mathbf{B}$ & Std. Error & & \\
\hline (Constant) & & $-0,059$ & 0,171 & & \\
\hline Tingkat Pendidikan $\left(\mathrm{X}_{1}\right)$ & & 0,305 & 0,100 & 3,054 & 0,005 \\
\hline Pengalaman Kerja $\left(\mathrm{X}_{2}\right)$ & & 0,396 & 0,117 & 3,380 & 0,002 \\
\hline Independensi $\left(\mathrm{X}_{3}\right)$ & & 0,132 & 0,062 & 2,143 & 0,041 \\
\hline Gaya Kepemimpinan $\left(\mathrm{X}_{4}\right)$ & & 0,165 & 0,076 & 2,164 & 0,040 \\
\hline Adjusted $R^{2}$ & 0,951 & & & & \\
\hline $\mathrm{F}$ & 152,75 & & & & \\
\hline Sig. F & 0.00 & & & & \\
\hline
\end{tabular}

Sumber: Data diolah, 2018

Berdasarkan Tabel 5analisis regresi linier berganda, maka dapat dibuat suatu persamaan regresi sebagai berikut.

$$
\mathrm{Y}=-0,059+0,305 \mathrm{X} 1+0,396 \mathrm{X} 2+0,132 \mathrm{X} 3+0,165 \mathrm{X} 4+e
$$

Persamaan regeresi diatas menunjukan nilai konstanta sebesar $-0,059$. Hal ini berarti jika variabel tingkat pendidikan $\left(\mathrm{X}_{1}\right)$, pengalman kerja $\left(\mathrm{X}_{2}\right)$, independensi $\left(\mathrm{X}_{3}\right)$, dan gaya kepemimpinan $\left(\mathrm{X}_{4}\right)$ nilainya adalah 0 , maka efektivitas Sistem 
Pengendalian Internal (Y) akan memiliki nilai negatif, nilainya adalah sebesar 0,059 .

Koefisien variabel tingkat pendidikan $\left(\mathrm{X}_{1}\right)$ sebesar 0,305, hal ini berarti jika variabel tingkat pendidikan bertambah satu satuan, maka variabel efektivitas Sistem Pengendalian Internal bertambah sebesar 0,305 dengan asumsi variabel lainnya konstan.Koefisien variabel pengalaman kerja $\left(\mathrm{X}_{2}\right)$ sebesar 0,396, hal ini berarti jika variabel pengalaman kerja bertambah satu satuan, maka variabel efektivitas Sistem Pengendalian Internal bertambah sebesar 0,396 dengan asumsi variabel lainnya konstan.

Koefisien variabel independensi $\left(\mathrm{X}_{3}\right)$ sebesar 0,132 , hal ini berarti jika variabel independensi bertambah satu satuan, maka variabel efektivitas Sistem Pengendalian Internal bertambah sebesar 0,132 dengan asumsi variabel lainnya konstan.Koefisien variabel gaya kepemimpinan $\left(\mathrm{X}_{4}\right)$ sebesar 0,165 , hal ini berarti jika variabel gaya kepemimpinan bertambah satu satuan, maka variabel efektivitas Sistem Pengendalian Internal bertambah sebesar 0,165 dengan asumsi variabel lainnya konstan.Nilai e(Error) dalam konsep statistika khususnya di dalam konsep regersi linier, error adalah semua hal yang mungkin memengaruhi variabel terikat Y, yang mungkin tidak diamati oleh peneliti.

Berdasarkan Tabel 5 koefisien determinasi yang disesuaikan (Adjusted $R$ Square) adalah 0,951. Nilai adjusted Rsquare sebesar 0,951, ini berarti sebesar 95,1 persen $(\%)$ variabel tingkat pendidikan, pengalaman kerja, independensi, dan gaya kepemimpinan berpengaruh terhadap efektivitas Sistem Pengendalian Internal, sedangkan sisanya sebesar 4,9 persen (\%) dipengaruhi oleh variabel lain 
yang tidak dimasukan dalam penelitian. Tabel 5 juga menunjukkan bahwa nilai $\mathrm{F}$ diperoleh sebesar 152,75 dengan tingkat signifikansi 0,00. Karena tingkat signifikansi 0,00 lebih kecil dari 0,05, ini berarti bahwa seluruh variabel yang digunakan dalam penelitian ini fit atau layak digunakan.

Berdasarkan Tabel 5 dapat dilihat bahwa terdapat pengaruh yang signifikan antara variabel tingkat pendidikan, pengalaman kerja, independensi, dan gaya kepemimpinan terhadap efektivitas Sistem Pengendalian Internal. Adapun penjelasan dari hasil uji t masing-masing variabel adalah sebagai berikut:

Hasil uji $\mathrm{t}$ untuk $\mathrm{H}_{1}$ diperoleh angka t-hitung sebesar 3,054 dengan signifikansi 0,005. Nilai signifikansi untuk variabel tingkat pendidikan menunjukkan nilai signifikansi dibawah tingkat signifikan sebesar 0,05 dan nilai t-hitung sebesar 3,054 > t-tabel sebesar 1,703 yang artinya $\mathrm{H}_{1}$ diterima atau ada pengaruh positif tingkat pendidikan terhadap efektivitas Sistem Pengendalian Internal. Hasil penelitian ini sejalan dengan penelitian (Mirawati, 2014) yang menyatakan bahwa tingkat pendidikan berpengaruh positif terhadap efektivitas Sistem Pengendalian Internal pada perusahaan tekstil di Sukoharjo. Hasil penelitian ini juga sesuai dengan hasil yang dicapai oleh(Stiawan, I Kadek Jonh, Edy Sujana, 2017) dimana tingkat pendidikan berpengaruh positif terhadap efektivitas Sistem Pengendalian Internal Lembaga Perkreditan Desa seKecamatan Banjar. Hasil penelitian ini mendukung teori stewardship, dimana Satuan Pengawas Internal sebagai steaward yang bertugas membantu pimpinan di masing-masing Instansi dalam hal pengawasan internal penting untuk memiliki tingkat pendidikan yang tinggi guna meningkatkan kemampuan dalam melakukan 
pengawasan sebagai upaya meningkatkan efektivitas Sistem Pengendalian Internal.

Hasil uji t untuk $\mathrm{H}_{2}$ diperoleh angka t-hitung sebesar 3,380 dengan signifikansi 0,002. Nilai signifikansi untuk variabel pengalaman kerja menunjukkan nilai signifikansi dibawah tingkat signifikan sebesar 0,05 dan nilai t-hitung sebesar 3,380 > t-tabel sebesar 1,703 yang artinya $\mathrm{H}_{2}$ diterima atau ada pengaruh positif pengalaman kerja terhadap efektivitas Sistem Pengendalian Internal.Hasil tersebut sesuai dengan hasil penelitian yang dicapai(Ekayanti et al., 2017) yang menyatakan pengalaman kerja berpengaruh positif dan signifikan terhadap efektivitas Sistem Pengendalian Internal pada Lembaga Perkreditan Desa se-kecamatan Payangan Kabupaten Badung. Hasil penelitian ini juga mendukung penelitian (Bhuaneswari \& Damayanthi, 2018) yang menyatakan pengalaman kerja berpengaruh positif terhadap efektivitas pengendalian internal LPD di Kota Denpasar.

Hasil penelitian ini mendukung teori stewardship, dimana Satuan Pengawas Internal sebagai steawardyang bertugas membantu pimpinan di masing-masing Instansi dalam hal pengawasan internal penting untuk memiliki pengalaman kerja yang memadai.

Hasil uji t untuk $\mathrm{H}_{3}$ diperoleh angka t-hitung sebesar 2,143 dengan signifikansi 0,041. Nilai signifikansi untuk variabel independensi menunjukkan nilai signifikansi dibawah tingkat signifikan sebesar 0,05 dan nilai t-hitung sebesar 2,143 > t-tabel sebesar 1,703 yang artinya $\mathrm{H}_{3}$ diterima atau ada pengaruh positif independensi terhadap efektivitas Sistem Pengendalian Internal. Hasil 
penelitian ini sesuai dengan penelitian (Putra et al., 2017) yang menyatakan independensi pengawas internal berpengaruh positif dan signifikan terhadap efektivitas Sistem Pengendalian Internal BUMDES Se-Kecamatan Kubutambahan Kabupaten Buleleng. Hasil penelitian ini juga sejalan dengan penelitian (Sudarta, 2017) yang menyatakan independensi berpengaruh positif dan signifikan terhadap efektivitas Sistem Pengendalian Internal LPD.

Hasil penelitian ini mendukung teori stewardship, dimana Satuan Pengawas Internal sebagai steawarddalam melakukan tugas pengawasan dan pemeriksaan harus dalam keadaan bebas dari pengaruh, tidak dikendalikan pihak lain, ataupun tergantung pada pihak lain, sehingga Satuan Pengawas Internal dapat mengungkapkan fakta atau temuan yang terjadi di Instansi tempatnya bekerja tanpa dipengaruhi kepentingan pribadi maupun Instansinya.

Hasil uji t untuk $\mathrm{H}_{4}$ diperoleh angka t-hitung sebesar 2,164 dengan signifikansi 0,040. Nilai signifikansi untuk variabel gaya kepemimpinan menunjukkan nilai signifikansi dibawah tingkat signifikan sebesar 0,05 dan nilai t-hitung sebesar 2,164 > t-tabel sebesar 1,703 yang artinya $\mathrm{H}_{4}$ diterima atau ada pengaruh gaya positif kepemimpinan terhadap efektivitas Sistem Pengendalian Internal. Hasil penelitian ini sejalan dengan penelitian (Wicaksono, 2013) yang menyatakan gaya kepemimpinan berpengaruh positif terhadap efektivitas Sistem Pengendalian Internal. Hasil penelitian ini juga sejalan dengan penelitian (Kibtiyah \& Sari, 2017) yang menyatakan gaya kepemimpinan berpengaruh positif terhadap efektivitas Sistem Pengendalian Internal pengadaan barang/jasa pemerintah di lingkungan Kementerian Agama Provinsi Bali. 
Hasil penelitian ini mendukung teori stewardship, dimana gaya kepemimpinan seorang pemimpin dianggap mempunyai peranan pada efektivitas Sistem Pengendalian Internal, gaya kepemimpinan yang diterapkan di PD Pasar, PD Parkir, dan PDAM sudah termasuk baik, dimana pimpinan instansi mapu bersikap tegas terhadap pegawainya berkaitan dengan tugas dan tangunggjawab yang harus dilaksanakan oleh pegawai, selain itu pimpianan Instansi juga sudah menyampaikan dengan jelas tujuan yang ingin dicapai ke masing-masing bagian dan pegawai serta mampu menghargai dan memberi inspirasi bagi pegawainya.

\section{SIMPULAN}

Berdasarkan analisis di bab-bab sebelumnya, maka dapat ditarik kesimpulan sebagai berikut: Tingkat pendidikan Satuan Pengawas Internal berpengaruh positif terhadap Efektivitas Sistem Pengendalian Internal BUMD Kota Denpasar; Pengalaman kerja Satuan Pengawas Internal berpengaruh positif terhadap Efektivitas Sistem Pengendalian Internal BUMD Kota Denpasar; Independensi Satuan Pengawas Internal berpengaruh positif terhadap Efektivitas Sistem Pengendalian Internal BUMD Kota Denpasar; dan Gaya kepemimpinan Satuan Pengawas Internal berpengaruh positif terhadap Efektivitas Sistem Pengendalian Internal BUMD Kota Denpasar. Penelitian yang dilakukan dapat memberikan kontribusi berupa bukti empiris yang mendukung teori stewardship. Hal ini karena Satuan Pengawas Internal sebagai steward yang bertugas membantu pimpinan instansi dalam melakukan pengawasan diharapkan mampu meningkatkan kapasitasnya melalui peningkatan tingkat pendidikan, pengalaman 
kerja, dan independensi serta gaya kepemimpinan yang diterapkan pimpinan Instansi juga penting diperhatikan sehingga kualitas pengawasan dan pemeriksaan yang dilakukan oleh Satuan Pengawas Internal akan semakin baik dan Sistem Pengendalian Internal di Instansi tersebut akan berjalan lebih efektif. Bedasarkan hasil penelitian dan simpulan yang diperoleh, terdapat beberapa saran yang dapat dikemukakan yaitu:BUMD yang ada di Kota Denpasar dimana dalam penelitian ini menggunakan sampel PD Pasar, PD Parkir, dan PDAM diharapkan terus meningkatkan efektivitas Sistem Pengendalian Internal di Instansinya masing-masing, karena dengan adanya Sistem Pengendalian Internal yang efektif diharapkan dapat meminimalkan kecurangan-kecurangan yang mungkin timbul dalam suatu Instansi seperti praktik korupsi, pengelolan pendapatan dan pengelolaan belanja yang tidak sesuai ketentuan, yang dapat menimbulkan kerugian bagi Negara maupun daerah tersebut.

\section{REFERENSI}

Abiola, I. (2013). Internal Control System on Fraud Detection: Nigeria Experience Ladoke Akintola University of Technology Ladoke Akintola University of Technology. Journal of Accounting and Finance, 13(5), 137149.

Apsari, N. N. S., \& Gayatri. (2018). Pengaruh Independensi, Gaya Kepemimpinan, Komitmen Organisasi, Pegalaman Kerja , dan Pemahaman Good Governance pada Kinerja Auditor. E-Jurnal Akuntansi Universitas Udayana, ISSN 2302-8556, 24(1), 282-310.

Bhuaneswari, A. A. A. M., \& Damayanthi, I. G. A. E. (2018). Pengaruh Karakteristik Pengawas Internal terhadap Efektivitas Pengendalian Internal Lembaga Perkreditan Desa di Kota Denpasar. E-Jurnal Akuntansi Universitas Udayana, 22, 1800-1825. 
Bisnis.com. (2017). BPK Ungkap Temuan Senilai Rp 19,48 triliun. Retrieved January 28, 2019, from https://www.google.co.id/amp/s/m.bisnis.com/amp/read/20170417/15/64558 2/bpk-ungkap-temukan-senilai-rp1948-triliun

Ekayanti, W., Sujana, E., \& Wahyuni, M. A. (2017). Pengaruh Budaya Organisasi, Gaya Kepemimpinan, dan Pengalaman Kerja Terhadap Efektivitas Sistem Pengendalian Intern Pada Lembaga Perkreditan Desa ( Lpd ) Se-Kecamatan Payangan Kabupaten Gianyar. E-JournalS1 Ak Universitas Pendidikan Ganesha, 1(3).

Kibtiyah, M., \& Sari, M. M. R. (2017). Pengaruh Kompetensi, Budaya Organisasi dan Gaya Kepemimpinan pada Efektivitas Sistem Pengendalian Intern Pengadaan Barang/Jasa Pemerintah Fakultas Ekonomi dan Bisnis Universitas Udayana , Bali , Indonesia Email : muhimatul.kibtiyah@gmail.com, 5, 18771908.

Kompas.com. (2018). Dugaan Korupsi Dana Revitalisasi Pasar, Pejabat BUMD Surabaya Ditahan. Retrieved January 28, 2019, from https://regional.kompas.com/read/2018/03/01/07171921/dugaan-korupsidana-revitalisasi-pasar-pejabat-bumd-surabaya-ditahan

Liputan6.com. (2018). Direktur BUMD Bogor Jadi Tersangka Korupsi Investasi Penyertaan Modal. Retrieved January 28, 2019, from https://www.google.co.id/amp/s/m.liputan6.com/amp/3635718/direkturbumd-bogor-jadi-tersangka-korupsi-investasi-penyertaan-modal

Merdeka.com. (2015). Kasus Korupsi PDAM, Terdakwa Hengky Rugikan Negara Sebesar Rp 45 M. Retrieved January 28, 2019, from https://www.google.co.id/amp/m.merdeka.com/amp/peristiwa/kasus-korupsipdam-terdakwa-hengky-rugikan-negara-sebesar-rp-45-m.html

Mirawati, E. (2014). Pengaruh Pendidikan, Pengalaman dan Pelatihan Kerja terhadap Efektivitas Sistem Pengendalian Internal (Survei pada Perusahaan Tekstil di Kabupaten Sukoharjo). Fakultas Ekonomi Dan Bisnis Universitas Muhammadiyah Surakarta, 8(33), 44.

Peraturan Pemerintah Republik Indonesia Nomor 54 Tahun 2017 tentang Badan Usaha Milik Daerah. (n.d.).

Putra, I. P. A. K., Herawati, N. T., \& Purnamawati, I. G. A. (2017). Pengaruh Independensi, Kompetensi, dan Ruang Lingkup Pekerjaan Pengawas Internal Terhadap Efektivitas Sistem Pengendalian Intern Bum Desa Se-Kecamatan. E-Jurnal S1 Ak Universitas Pendidikan Ganesha, 8. 
Rose, V. (2015). Peran Internal Auditor dalam Meningkatkan Efektivitas Pengendalian Internal Industri Perbankan. Skripsi . Fakultas Ekonomi Dan Bisnis Universitas Katolik Soegijapranata Semarang.

Soimah, S. (2014). Pengaruh Kapasitas Sumber Daya Manusia, Pemanfaatan teknologi Informasi, dan Sistem Pengendalian Intern Pemerintah terhadap Kualitas Laporan Keuangan Pemerintah Daerah Kabupaten Bengkulu Utara. Skripsi. Jurusan Akuntansi Fakultas Ekonomi Dan Bisnis Universitas Bengkulu.

Stiawan, I Kadek Jonh, Edy Sujana, I. N. P. Y. (2017). Pengaruh Pengalaman Kerja, Profesionalisme, Tingkat Kompensasi, dan Tingkat Pendidikan Badan Pengawas terhadap Efektivitas Sistem Pengendalian Internal pada Lembaga Perkreditan Desa Se-Kecamatan Banjar e-Journal S1 Ak Universitas Pendidikan Ganesha. E-Journal S1 Ak Universitas Pendidikan Ganesha, 1.

Sudarta, P. (2017). Pengaruh Independensi, Gaya Kepemimpinan, Pengalaman Kerja Dan Kompetensi Pemimpin Terhadap Efektivitas Sistem Pengendalian Intern Pada Lpd Se-Kecamatan Banjar, 7(1).

Wardani, R. N. (2014). Pengaruh Tingkat Pendidikan, Pengalaman Kerja, dan Pengendalian Internal terhadap Kualitas laporan Keuangan pada Kantor Kementerian Agama Kota Makasar. Skripsi. Fakultas Ekonomi Dan Bisnis Islam Universitas Islam Negeri (UIN) Alaudin Makasar.

Wicaksono, W. C. (2013). Faktor-faktor yang Mempengaruhi Efektivitas Pengendalian Intern di Sektor Pemerintahan (Persepsi Pegawai pada Dinasdinas Kota Semarang).

Wijaya, W. A., Arifati, R., \& Suprijanto, A. (2016). Analisis Pengaruh Independensi, Motivasi, Pengalaman Kerja, Profesionalisme, dan Gaya Kepemimpinan terhadap Efektivitas Penerapan Sistem Pengendalian Intern ( Studi Empiris pada Auditor Internal yang Bekerja di Perusahaan Pembiayaan se- Kabupaten Kudus ). Mмum, 2(2), 2016. 